Revue musicale OICRM

\title{
Debussy's Cakewalk. Race, Modernism and Music in Early Twentieth-Century Paris
}

\section{James Deaville}

Volume 2, numéro 1, 2014

La réception de Debussy au XXe siècle. Incidences, influences et autorité

URI : https://id.erudit.org/iderudit/1055844ar

DOI : https://doi.org/10.7202/1055844ar

Aller au sommaire du numéro

Éditeur(s)

OICRM

ISSN

2368-7061 (numérique)

Découvrir la revue

Citer cet article

Deaville, J. (2014). Debussy's Cakewalk. Race, Modernism and Music in Early Twentieth-Century Paris. Revue musicale OICRM, 2(1), 20-39.

https://doi.org/10.7202/1055844ar
Résumé de l'article

Entre novembre 1902 et janvier 1903, les parisiens s'initient au cake-walk dansé à travers les représentations de deux troupes américaines en tournée : "Les Elks " et leur troupe de danseur noire et blanc apparaissent dans la revue Les joyeux nègres au Nouveau Cirque, alors que les « Florida Creole Girls » sept femmes afro-américaines - dansent le cake-walk au Casino de Paris. Dans l'espace de quelques semaines, cette danse devient la nouvelle sensation de la capitale, comme il est indiqué dans l'édition de janvier 1903 de la revue Paris qui change, ce qui s'accompagne de quelques dissensions. C'est dans ce contexte culturel particulier que Debussy s'introduit dans le monde de la musique américaine syncopée avec son Golliwogg’s Cake-walk des Children's Corner (1908). Cette œuvre est suivie par The Little Nigar (1909), dont il réutilise le thème dans La boîte à joujoux (1913) ; puis, par Minstrels du premier livre de Préludes (1910), qui reprend les rythmes du cake-walk de façon plus subtile ; enfin, «General Lavine »-eccentrique du deuxième livre (1910-1913), dans laquelle il utilise la désignation « Dans le style et le mouvement d'un cake-walk ». Alors que la littérature au sujet de Debussy et de la musique au tournant du siècle fait référence à la dette de Debussy à l'égard du cake-walk et du ragtime, elle a bien souvent échoué à situer le compositeur dans le discours qui prévalait au sujet de la danse, ce qui inclut le film Le cake-walk infernal (1903) de Georges Méliès. Cet article entend explorer les quatre œuvres de Debussy dans la perspective du débat contemporain sur le cake-walk dans la société et la culture françaises. Plutôt que d'attribuer une posture particulière au compositeur eu égard à la culture noire à travers l'appropriation du cake-walk, nous allons nous intéresser à ce que représentait pour Debussy la prise en charge des éléments de la société parisienne qui englobaient la danse et sa musique. Toutefois, comme le cas de Debussy et de son milieu parisien le montrera, l'appropriation moderniste du cake-walk ne peut ignorer les appréhensions problématiques entourant la race.
Ce document est protégé par la loi sur le droit d'auteur. L’utilisation des services d’Érudit (y compris la reproduction) est assujettie à sa politique d'utilisation que vous pouvez consulter en ligne.

https://apropos.erudit.org/fr/usagers/politique-dutilisation/ 


\title{
Debussy's Cakewalk. Race, Modernism and Music in Early Twentieth-Century Paris
}

\author{
James Deaville
}

\begin{abstract}
Résumé
Entre novembre 1902 et janvier 1903, les parisiens s'initient au cake-walk dansé à travers les représentations de deux troupes américaines en tournée : "Les Elks" et leur troupe de danseur noire et blanc apparaissent dans la revue Les joyeux nègres au Nouveau Cirque, alors que les "Florida Creole Girls "- sept femmes afroaméricaines - dansent le cake-walk au Casino de Paris. Dans l'espace de quelques semaines, cette danse devient la nouvelle sensation de la capitale, comme il est indiqué dans l'édition de janvier 1903 de la revue Paris qui change, ce qui s'accompagne de quelques dissensions. C'est dans ce contexte culturel particulier que Debussy s'introduit dans le monde de la musique américaine syncopée avec son Golliwogg's Cake-walk des Children's Corner (1908). Cette œuvre est suivie par The Little Nigar (1909), dont il réutilise le thème dans La boîte à joujoux (1913) ; puis, par Minstrels du premier livre de Préludes (1910), qui reprend les rythmes du cake-walk de façon plus subtile ; enfin, "General Lavine »-eccentrique du deuxième livre (1910-1913), dans laquelle il utilise la désignation "Dans le style et le mouvement d'un cakewalk ». Alors que la littérature au sujet de Debussy et de la musique au tournant du siècle fait référence à la dette de Debussy à l'égard du cake-walk et du ragtime, elle a bien souvent échoué à situer le compositeur dans le discours qui prévalait au sujet de la danse, ce qui inclut le film Le cake-walk infernal (1903) de Georges Méliès. Cet article entend explorer les quatre œuvres de Debussy dans la perspective du débat contemporain sur le cake-walk dans la société et la culture françaises. Plutôt que d'attribuer une posture particulière au compositeur eu égard à la culture noire à travers l'appropriation du cake-walk, nous allons nous intéresser à ce que représentait pour Debussy la prise en charge des éléments de la société parisienne qui englobaient la danse et sa musique. Toutefois, comme le cas de Debussy et de son milieu parisien le montrera, l'appropriation moderniste du cake-walk ne peut ignorer les appréhensions problématiques entourant la race.
\end{abstract}

Mots clés : cake-walk; Golliwogg’s Cake-walk; Georges Méliès ; modernisme ; race.

\footnotetext{
Abstract

Between November, 1902 and January, 1903, Paris experienced its first tastes of the danced cakewalk through the performances of two American touring ensembles:
} 
"Les Elks" and their troupe of black and white dancers appeared in the revue Les joyeux nègres at the Nouveau Cirque, while the "Florida Creole Girls" - seven African-American women-performed the cakewalk at the Casino de Paris. Within a matter of weeks the dance became the latest sensation of the capital, as reported in Paris qui chante of January, 1903, although not without serious dissension. It was upon this field of social and cultural contestation that Debussy entered into the world of syncopated Americanism with Golliwogg's Cake-Walk from the Children's Corner (1908). This was followed by The Little Nigar (1909), the theme of which he reused in Le boite à joujoux (1913); Minstrels from the first book of Préludes (1910), which more subtly draws upon cakewalk rhythms; and "General Lavine"Eccentric from the second book (1910-1913), for which he uses the tempo designation "Dans le style et le mouvement d'un cake-walk." While the literature about Debussy and fin-de-siècle music does reference this music and his indebtedness to the cakewalk and ragtime, it has largely failed to position him within the prevailing discourse surrounding the dance, which includes the film Le cake-walk infernal by Georges Méliès (1903). This paper proposes to explore the four aforementioned works by Debussy from the perspective of the contemporary debate over the cakewalk in French culture and society. Rather than attributing to the composer a particular subject position regarding blacks and their culture through his appropriation of the cakewalk, we will explore what it meant for Debussy to align himself with those elements of Parisian society that embraced the dance form and its music. However, as we shall see in the case of Debussy and his Parisian milieu, the modernist adoption of the cakewalk was fraught with problematic constructions of race, which cannot be ignored.

Keywords: cakewalk; Golliwogg's Cake-Walk; Georges Méliès; modernism; race.

With the release of Hugo in 2011, director Martin Scorsese provided the film audience with a loving look back to a time in cinematic history when the work of French film-makers like the Lumière Brothers and Georges Méliès populated Parisian entertainment venues. ${ }^{1}$ This was the world that experienced Méliès' celebrated Le voyage dans la lune (1902) and Le cake-walk infernal (1903) to the amazement of audiences, the latter featuring a blackface couple negotiating the dance's steps in the halls of hell. And this was the world that Claude Debussy inhabited, where blackface minstrelsy and the cakewalk danced by African Americans coexisted on stages and film screens.

This era, as well as the decades that followed in France (and elsewhere), have been designated as "Modernism" by hosts of scholars, but not without strong contestations that have cut across disciplines. Russian linguist Roman Jakobson famously responded to the problem of the term's polysemy by observing, "I try not to use even Modernism, because what is Modernism, it depends on who writes it and at what

1 I wish to thank François de Médicis (Université de Montréal), Tobias Fasshauer (HumboldtUniversität zu Berlin) and Catherine Kautsky (Lawrence University) for valuable insights that I used in preparing the article version of my paper. The anonymous reviewer also provided useful recommendations for revisions. Agnes Malkinson (Carleton University) was most helpful in preparing the final version of the essay. Although the terms of early jazz - ragtime, cakewalk, syncopated-are variable, I will focus here on the syncopated dance the French themselves identified as "cake-walk" or "danse de gâteau," since that is the form of early jazz known and imitated by Debussy. 
moment" (Jakobson [1979]1985, p. 171). As Noel Orillo Verzosa argues in detail in his dissertation, even during the time of Debussy, music and other arts critics were vigorously debating the concept and its characteristics and validity, ${ }^{2}$ so that it may be impossible to attain to any kind of universal definition or description, even though Daniel Albright makes an attempt with the following formulation: "...for the purposes of this book, the definition of Modernism is (tentatively) as follows: the testing of the limits of aesthetic construction. According to this perspective, the Modernist tried to find the bounds of certain artistic traits..." (Albright 2000, p. 30).

Despite his tentativeness, Albright nevertheless does capture something of the culture of early twentieth-century France in the phrase "testing the limits of aesthetic construction," with the era's veneration of the vernacular, fetishization of racial difference, and fascination with extremes of physical culture. The cakewalk of African-American entertainers in pre-war Paris brought together these characteristics in a nexus of converging practices and preferences that resulted in what theatre scholar Przemysław Strożek has called "a veritable explosion of cakewalk mania in the French capital" (Strożek 2013, p. 47). And it was just the "alien bodies" of the black entertainers that dance specialist Ramsay Burt designated as "a central subject of modernist dance" (Burt 1998, p. 6). Although négrophilie would find its peak in the Paris of the 1920s and its craze over Josephine Baker (Gendron 1990), the cakewalk performances of African Americans beginning in 1902 definitely contributed to the evolution of the discourse.

Despite the fact that Debussy was surrounded by and absorbed such French Modernist attitudes towards race, few scholars have explored those particular connections that would bear such fruit in his music. However, in 1986, Ann McKinley published the article "Debussy and American Minstrelsy" (McKinley 1986), a study that-while apparently the first scholarly attempt to consider the composer's four piano pieces ostensibly derived from the cakewalk as a group ${ }^{3}$ - remains by and large uncited in the Debussy literature. McKinley analytically pointed out those features that identify the pieces as having a basis in "minstrelsy" and provided a brief biography for Debussy's potential contact with the style, but did not develop the arguments any further. However, she remains the only musicologist to take a closer look at all four of Debussy's cakewalk-based pieces.

The intervening twenty-five years have brought a wealth of studies about music and fin-de-siecle Parisian culture, ${ }^{4}$ and both Debussy and the cakewalk have prominently

2 See Chapters 1, 2, and 3 of the $\mathrm{PhD}$ dissertation "The Absolute Limits. Debussy, Satie, and the Culture of French Modernism, ca. 1860-1920” (Orillo Verzosa 2009).

3 Golliwogg's Cake-Walk, from Children's Corner (1906-1908), publ. 1908; The Little Nigar (1909), publ. 1909; Minstrels, from Préludes, Book 1 (1910), publ. 1910; "General Lavine"-Eccentric, from Préludes, Book 2 (1911-1913), publ. 1913. Some authors call this grouping of compositions "ragtime-based" or simply "rags"-Matthew Brown's recent study of Debussy's influence on popular culture observes that "During the five-year period from 1908 to 1913, he composed four piano rags" (Brown 2012, p. 6). However, this designation fails to identify the compositions' origins and to recognize their stylistic traits.

4 See the anthology Music, Theater, and Cultural Transfer. Paris, 1830-1914, edited by Annegret Fauser and Mark Everist (2009); Steven Huebner's French Opera at the Fin-de-Siècle. Wagnerism, Nationalism, and Style 
figured in that literature, although most often not in the same breath. When they do coincide, the reference is usually to Golliwogg's Cake-Walk, ${ }^{5}$ which has come to serve as a synecdoche for that aspect of Debussy's work and thought.

The purpose of this essay is to review the literature and explore its representations of Debussy's relationship with what we might term the "cakewalk tradition" (Deaville 2002) while examining some of the sources from the time and positioning and re-positioning the composer within the French fin-de-siècle racial discourse. The debate over whether Debussy was or was not racist in composing this music is of little value, for as Robert Orledge observes in the Cambridge Companion to Debussy, "it is doubtful if Debussy's views were any more sexist or racist than the rest of his politically incorrect generation" (Orledge 2003, p. 13). Here I am interested in investigating the context in which Debussy was composing these pieces and what it may have meant for him to adopt elements of the pre-jazz cakewalk style into his work. ${ }^{6}$

\section{Debussy's Approach to the Cakewalk Style}

Before exploring that milieu, however, it is necessary to consider Debussy's specific uses of the cakewalk materials in the four piano pieces in question, for each deployment occurs in a different context. In attempting to impose structure and hierarchy within the grouping, McKinley divides the compositions into two equal pairs, those intended for young people (Golliwogg's Cake-Walk and The Little Nigar) and those of greater pretension (Minstrels and "General Lavine"-Eccentric), ${ }^{7}$ a distinction that does not bear any real analytical weight. It is true that both compositions from the books of Préludes are slightly longer and more complex than The Little Nigar, yet so is Golliwogg's Cake-Walk-however, the two later works do significantly depart from the dance as stylistically, formally and even melodically presented in the earlier pieces. Above and beyond considering the relative degrees of Debussy's adherence to an originary cakewalk style, the analyst of this music should query what he did with the "borrowed" material and whether musical racialisms exist in the (re-)workings.

One need not open the music of Children's Corner to experience Golliwogg's Cake-Walk, which is implicated in a discourse of racialized identity by Debussy's cover design: the disembodied head of the doll floats on a string held by Jimbo the elephant. Musicologist Linda Cummins describes this illustration as a

(1999), and more generally, Vanessa R. Schwartz's Spectacular Realities. Early Mass Culture in Fin-de-siècle Paris (1998), among others.

$5 \quad$ See for example Lawrence Kramer, Opera and Modern Culture. Wagner and Strauss (2004, p. 112-114); Davinia Caddy, "Parisian Cake Walks" (2007); Gregory Marion, "Debussy and Recollection. Trois apercu [sic]" (2007), at: http://www.mtosmt.org/issues/mto.07.13.1/mto.07.13.1.marion.html\#FN44 (accessed 1st June, 2013); and Elizabeth de Martelly, "Signification, Objectification, and the Mimetic Uncanny in Claude Debussy's 'Golliwogg's Cake-walk'” (2010).

6 It should be remembered that in Debussy's day, jazz as such did not yet exist, only in styles like ragtime and the cakewalk and in other forms featured in minstrelsy.

7 Of the latter two she writes, "Let us... join the adults, amusing themselves at the cafe concerts..." (McKinley 1986, 252). 
"grotesque," redolent of Odilin Redon's disembodied heads (Cummins 2006, p. 137). Debussy's ostensibly satirical references to the Tristan prelude and the Tristan chord have so preoccupied musicologists and theorists that few have ventured to discuss the frame for those passages, ${ }^{8}$ with the implication that the dance form itself represent low or trivial culture (the proper place for Wagner). Yet the composer does give us a cakewalk, in its overall structure (ABA, with the return to A fairly literal), characteristic opening cakewalk rhythm, left-hand vamping, and standard chord progressions (in the A section). Given the collection's cover art of the "grotesquerised" Golliwogg, the analyst must wonder whether the piece has more to do with the racial identity of the cakewalk than with Wagner's "high" art.

The Little Nigar' — usually considered a modest companion piece to Golliwogg's Cake-Walk ${ }^{10}$ _may present the melodic material of the dance in an even more straightforward manner, but it formally complicates the cakewalk through an $A B A B A$ structure, repeating the Trio section and the closing return of $A$. Otherwise it represents Debussy's most orthodox rendition of the cakewalk, albeit not without his characteristic offsetting touches, in this case the rising and falling chromatic-third accompaniment after statements of the theme. ${ }^{11}$

With Minstrels and "GeneralLavine"-Eccentric from the two books of Préludes, Debussy turns from the cakewalk model towards freer adaptations, from "authentic" black subjects (Golliwogg, "nigar") to their white imitators (minstrels, General Lavine). The rationale for this apparent shift remains unexplored, but the distance from the originating dance was great enough to warrant Debussy to place the following tempo marking at the head of "General Lavine"-Eccentric: "Dans le style et le mouvement d'un cake-walk." Siglind Bruhn maps out the descriptive musical materials of both pieces in terms of imagined scenarios for the minstrels or clown (Bruhn 1997), and as she argues, Minstrels is marked by a "deliberate awkwardness of rhythm and harmonic progress" (ibid., p. 115) yet the music accomplishes more than merely illustrating its professed subjects: it participated in a type of triple parody, by imitating the minstrels or clown parodying blacks whose cakewalk satirized their "masters". Both of these pieces consist of fragments, known and unknown, ${ }^{12}$ which suggests the variety of the minstrel and the circus show, yet at a deeper level may also reflect the

8 For analyses of the work's Wagnerian aspects, see (among others) Marion 2007; Kramer 2004, p. 113-115; and Caddy 2007, p. 308-310.

9 This is the original title of Debussy, which has been sanitized to "The Little Negro" or "Le Petit Nègre." According to McKinley, the work "was commissioned by Theodore Lack, a member of the piano faculty at the Paris Conservatoire, for inclusion in his Méthode de piano published in 1909" (McKinley 1986, p. 250).

10 Richard Taruskin implies that "Le Petit Nègre" is an alias for the Golliwogg. See "The First Modernist," in The Danger of Music and Other Anti-Utopian Essays (Berkeley, CA, University of California Press, 2008, p. 197).

11 Debussy reused the theme from The Little Nigar four years later in the children's ballet La boite à joujoux (1913).

12 Debussy makes musical reference to the cakewalk, the fanfare, and Broadway song, among other stylistic models. 
complexity of the (racially?) divided modern subject (Smethurst 2011, p. 220 note 10). Both clowns and minstrels of Debussy's time were caught up in discourses of identity surrounding the real and imagined African/black-American presence, to the extent that the performers made them "products for Parisian consumers" (Gordon 2009, p. 160). Debussy's musical sketches of the ostensibly white characters of the minstrels and General Lavine, with their whimsical forms, seemingly incongruous quotations and shifting rhythms, may well have accomplished more profound cultural work than merely entertaining the Parisians.

\section{Cakewalk in the French Cultural Context}

Perhaps the most thorough study of the cultural context for Debussy's cakewalk-related music is by Jody Blake in her book Le Tumulte Noir. Modernist Art and Popular Entertainment in Jazz-Age Paris, 1900-1930 (1999). At the heart of her argument is the period's négrophilie, which enabled the French to welcome such manifestations of "l'âme noire" like "l'art nègre" and the cakewalk or "danse du gâteau," the latter chronologically preceding the former. ${ }^{13}$ In fact, the Parisian public enjoyed physical contact with the new style from America already in 1900, if not earlier, with John Philip Sousa's band performances in the context of the Exposition Universelle (Bierly 2006, p. 24-25). He brought pieces for which he and the composers used the term "rag time," but which in reality were cakewalks, for example Abe Holzmann's Smoky Mokes and Kerry Mills' At a Georgia Camp Meeting, and which the French themselves designated as cakewalks. The dance was not new to the French, whose newspapers carried reports from the United States in the 1890s and who could learn to dance the cakewalk themselves as early as 1899 (Lussan-Borel 1899).

However, it was first in late 1902 that the cakewalk landed in Paris with stage performances, resulting in a public craze that assured longer term engagements for practitioners in the variously designated variety theatres. Blake argues that the public enthusiastically embraced the dance as "a specifically black musical performance" (Caddy 2007, p. 289), rather than rejecting it on the basis of racist prejudice: indeed, in the cakewalk they possessed proof of their racial superiority, which enabled them to indulge in its scandalously primitive motions as a manifestation of modernism. As Caddy summarizes Blake, "white appropriative desires... fashioned an imagined 'otherness,' a reified racial presence considered primarily as primitive and grotesque..." (Lussan-Borel 1899). And here is Blake herself: "It was because . . . the cake walk seemed to represent the capitulation of 'civilization' to 'savagery' that Parisians embraced [it]" (Blake 1999, p. 18). The modernist European-and specifically French-negrophilia that consumed this exotic dance of course positioned it within their own cultural practices, whether dance, cinema or even "classical" composition.

13 Regarding the use of these terms, see for example Joachim Schultz, "Ulysse, Cafre, ou l'histoire dorée d'un noir. Le roman de Marius et Ary Leblond dans le contexte de la littérature française des années vingt" (1990), and Pierre Akinwande, Négritude et francophonie. Paradoxes culturels et politiques (2011). 
Caddy's own contribution to the discussion of the cakewalk in Paris attempts to provide an alternative reading to racially-based interpretations. By examining the cakewalk's role in relation to the diverse forms of popular culture in Paris at the time and situating it within larger class issues of the fin-de-siècle, she makes a valuable intervention in what one could regard as a hyper-racialized discourse surrounding the modernist historical appropriation of primitivist cultural products. That many of the dance's French practitioners and consumers were not experiencing it directly in reference to its African or African-American heritage is an important observation. However, in arguing for the dance's broad middle-class appeal, she also succeeds in erasing race from the experience of the cakewalk, which she carries over into the analysis of Golliwogg's Cake-Walk - its real interest for her resides in the notorious Wagner quotations rather than its connections to black musical practices.

In the end, Caddy argues for a reading of the cakewalk's popularity as ultimately embedded in a wide array of French cultural practices at the time, including American chic, athleticism, the other-worldly and the clown, and thus more culturally ambivalent and socially in flux than presented in the literature. While these factors undoubtedly contributed to the dance's popularity in Paris at the time, overemphasizing them tends to de-racialize the cakewalk, at the cost of ignoring the presence of African-American performers on Parisian stages throughout the period, passing over the important cultural contributions of the black clown Chocolat except in the context of Debussy's meeting with him, and disregarding Debussy's other cakewalk-influenced music (especially The Little Nigar and Minstrels). And for Golliwogg's Cake-Walk, she neglects the crucial issue of Debussy's own grotesque, (dis-)embodied image of the doll's head on the cover of Children's Corner.

Lawrence Kramer provides a detailed analysis of the Wagner quotation in Golliwogg's Cake-Walk in his Opera and Modern Culture. Wagner and Strauss (Kramer 2004, p. 112-114), but of greater interest here is his earlier discussion of Minstrels in the essay "Powers of Blackness. Africanist Discourse in Modern Concert Music" (Kramer 1996). ${ }^{14}$ There he presents an interpretation of Minstrels where colonizer and colonized have something to say to each other, where the music serves at once as a:

Conduit for the material pleasure of Africanized bodies in song and dance... [and as] disciplined elements of structure... It remains, and is meant to remain, unclear whether sonority as pleasure is being curbed by the dominant function or the dominant function is being undone by sonority as pleasure (ibid., p. 66).

Thus Kramer proposes for this piece a way of listening that allows us to appreciate its play of difference-but his is not an historically grounded reading.

14 Kramer also passes over the cover illustration for Debussy's collection, which would bolster his argument for the fragmentation of "symbolic forms broken by modernity" (Kramer 1996, p. 114). 


\section{An Inside View of Debussy's Contacts With the Cakewalk}

It is necessary to have taken space to address the literature in some detail, in order to make the case for how recent studies have not really brought us much closer to understanding Debussy's potential contacts with the cakewalk. At its extremes, the research leaves us caught between potentially over-racialized and under-racialized interpretations. Although this essay cannot claim to answer the question definitively, it can present at least some of the factors that were in play within his milieu, factors that could have influenced him to work with this musical material.

First of all, it is necessary to explain the background of the cakewalk, although its origins remain a matter for debate. ${ }^{15}$ Whatever its specific origins, the cakewalk developed as a form of parody among African-American slaves, whose exaggerated movements mimicked those of the plantation owners. Competitions would be held with a cake as the prize. It developed in the United States into a popular social dance of the late nineteenth century for both blacks and whites, and then was taken to Europe after 1900. Key elements involved a mock dignity, undercut by what contemporaries identified as primitive gestures, unnatural bodily positions and grotesque movements.

The opening position of the dance, with back bent backwards, hands extended and knees bent as much as possible, communicates to us how the French must have physically experienced this modern primitivist dance. In this illustration, which appeared at the peak of the craze in 1904, we see a biracial couple in the intentionally awkward position, promoting the new dance - the black male presence on the sheet music would have conveyed authenticity, while the white female suggests the dance's appropriation by French culture (and possibly ease of execution, given her facial expression). The cakewalk would become a mainstay of French notions of "l'âme noire," in which African and African-American cultures are conflated into rituals and practices that stand low on the evolutionary scale.

15 Fletcher (1984, p. 103) argues for its origins in the chalk-line walk, while others claim that it arose directly from the parodying of plantation masters (see Waldo 1991, p. 25). Krasner best sums up the situation with the comment, "the origins of the cakewalk are inchoate at best" (Krasner 2011, p. 113). 


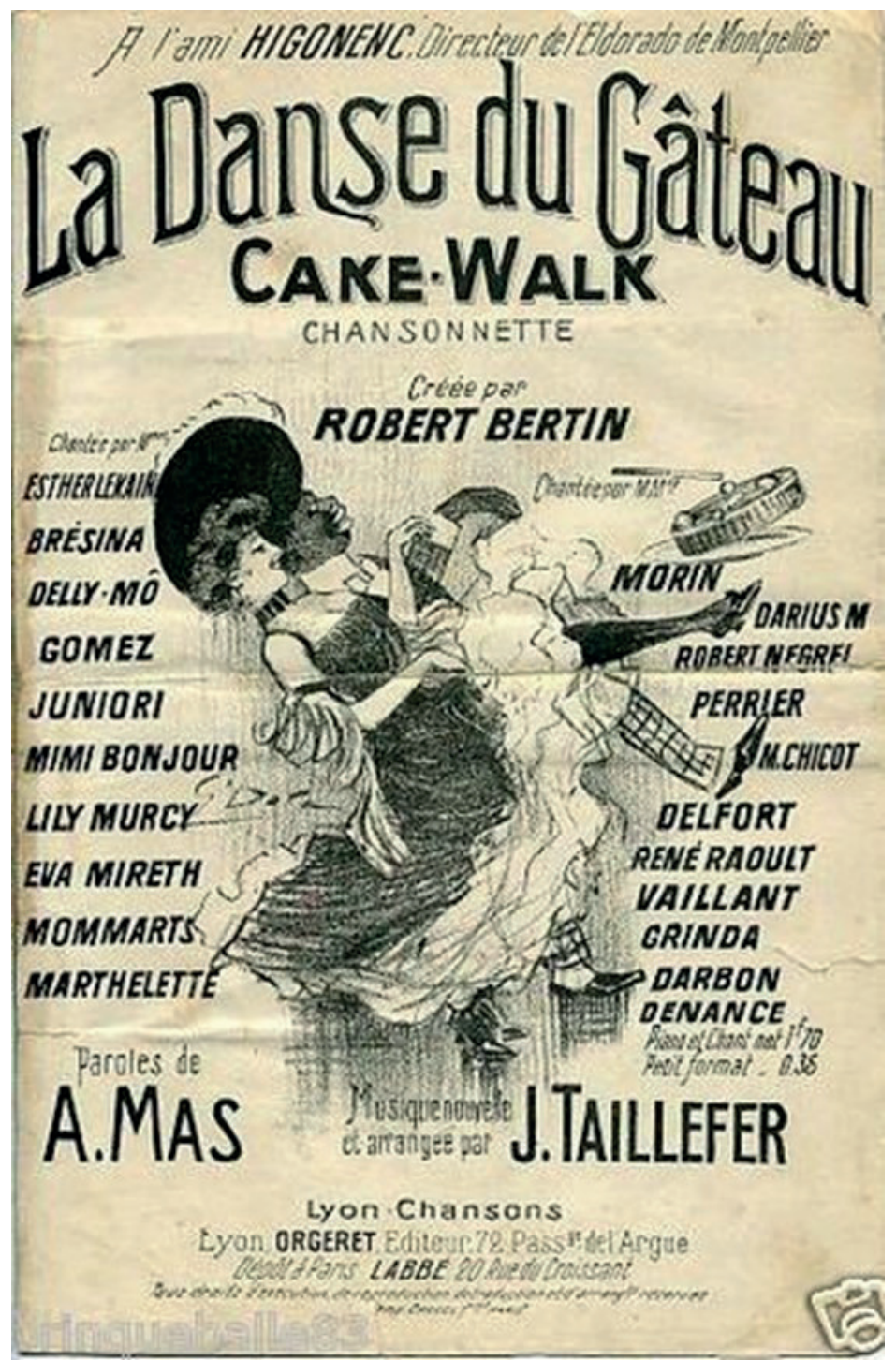

Figure 1: Jean Taillefer, La danse du gâteau, opening position, Lyon, Orgeret, 1904.

The following quotation represents how a Parisian journalist under the pseudonym Surtac (Gabriel Astruc in real life) described the dance's initial stance and motion in an article from Le Figaro from November 1902:

Needless to say, this plum pudding step has nothing graceful about it... The dancer throws his body to the front and his shoulders to the rear, assuming the curve of a stretched bow. Meanwhile, he raises his arms to a horizontal position, bent at the elbow... Thus positioned, and keeping watch on his unstable equilibrium, he thrusts one foot in front of himself, then the other in alternation, raising the knee as high as he can manage.

The music itself typically involves a simple alternation between one beat or measure of a short-long-short syncopation and a series of equal values, eighth or sixteenth notes, more straightforward than ragtime but still an expression of pre-jazz. It is extended by repetitions and a trio that maintains the pace but presents new material. 
As an example, the January 31, 1903 issue of Paris qui chante provides the music (with accompanying image) for the Célèbre cake walk. The music clearly reflects the basic form and pattern characteristic of the cakewalk - the alternation of a syncopation followed by four sixteenth notes is almost unbroken. The illustration portrays Les Elks and their full, racially mixed ensemble from the Nouveau Cirque in a cakewalk, with a strategically placed "négrillon" at the head of the troupe. ${ }^{16}$ The composer's name is indicated as Onin Arober, which is a retrograde of Italian composer Nino Rebora, who composed opera in the late nineteenth century. ${ }^{17}$

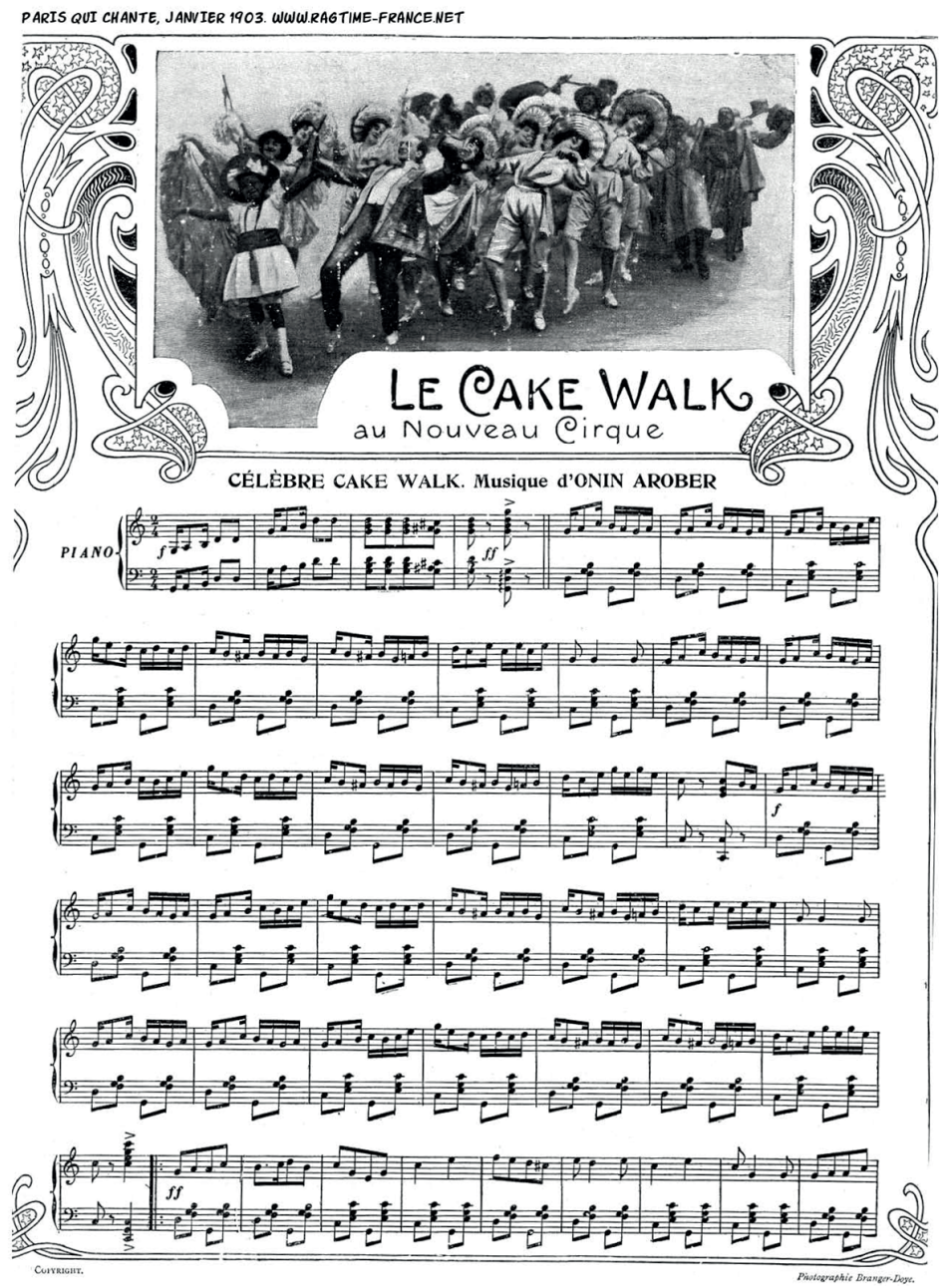

Figure 2: Onin Arober [=Nino Robera], Célèbre cake walk, Paris qui chante, January 31, 1903.

16 Les Elks included two young African-Americans in their Parisian programs, and they were known as the "Négrillons" (see Caddy 2007, p. 298). Auguste Lumière directed a six-minute film of the troupe's performance at the Nouveau Cirque in 1902, which may have influenced Georges Méliès in his own Le cake-walk infernal of 1903.

17 Rebora's dates are not definite, but his work includes the scena lirica Vendetta Catalana that was first performed in Turin in 1883. However, the identification is uncertain at best, since no other music seems to exist under the name Arober, and Rebora published no popular music. 
The rich aggregate of sources suggests that it would have been difficult for a resident of Paris during the first decade of the twentieth century not to have at least heard about the cakewalk and its craze. Walking down the Rue Vivienne in late 1903, the sheet music for Pierre Létorey's Cake-walk-polka sur des motifs de Louis Varney or Jean Taillefer's $L a$ danse du gâteau might appear in the window of the venerable shop Au Ménestrel, ${ }^{18}$ the pedestrian would see posters for performances at one of the variety theatres, and prominent advertisements for the latest shows and visiting artists would be featured in the daily or boulevard press.

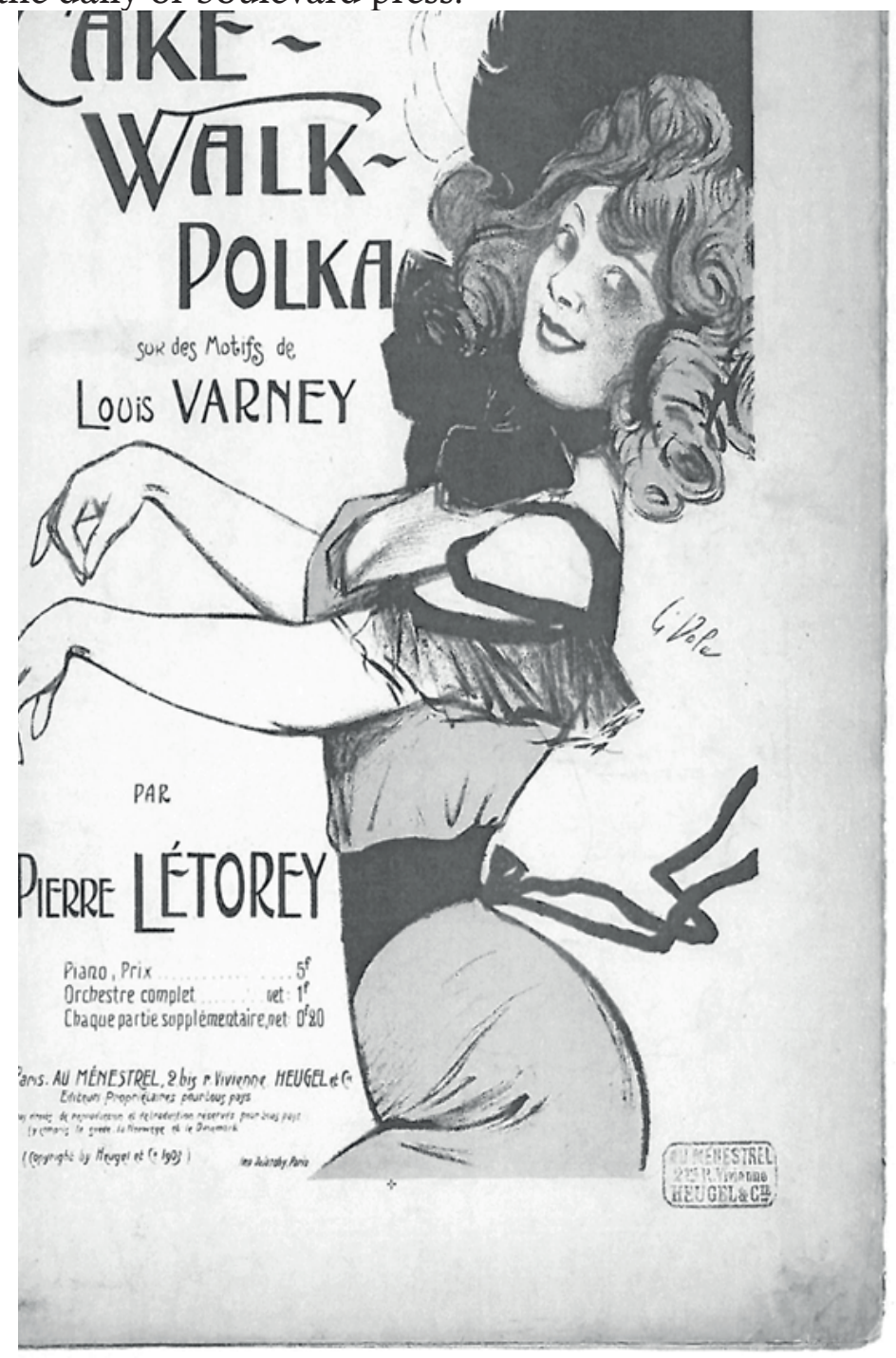

Figure 3: Pierre Létory, Cake-walk-polka sur des motifs de Louis Varney, Paris, Au Ménestrel, 1903.

18 Those two French cover images represent white women - in one case alone, in the other with a black male - in the easily recognizable opening pose of the cakewalk. Like other such covers, they portray the dance as pleasurable despite its unconventional demands on the body, whereby the sheet music functions not unexpectedly as a marketing tool. 
If this advertising accomplishes its task, the Parisian might attend a presentation of the cakewalk at the Nouveau Cirque by the white couple Les Elks with their black side-act "Les Négrillons" or the African-American troupe the Florida Creole Girls at the Casino de Paris. Inspired by these performances, the fan(atic) could subsequently take lessons in the cakewalk-whether from a teacher or from a set of published instructions in the sheet music-, and dance it in a variety of public and private fora, even participating in a danse du gâteau competition. And one could see the aforementioned Méliès film Le cake-walk infernal at the Théâtre Robert-Houdin. Thus, whether or not he/she supported or participated in the cakewalk mania of the time, the Parisian would have almost inevitably had various points of contact with it, with its racial contexts.

A closer look at the performances, sheet music and press responses assists in obtaining to a better understanding of Debussy's milieu. After Sousa's introduction of the cakewalk, Parisians had to wait two years to see it danced: the white American couple Les Elks immediately made a sensation in October of 1902 at the Nouveau Cirque when they performed the dance in a conventionalized contest called "Les Joyeux Nègres". ${ }^{19}$ A clever example of cross-promotion, the publicity photograph features the popular couple in a pose from the cakewalk that is explained by the instructional description ("théorie") below-this card appeared in a series devoted to the various steps of the dance, thereby promoting the act, the dance and the cards themselves (the cakewalk enthusiast would have to collect all of the cards to be able to replicate the dance steps).

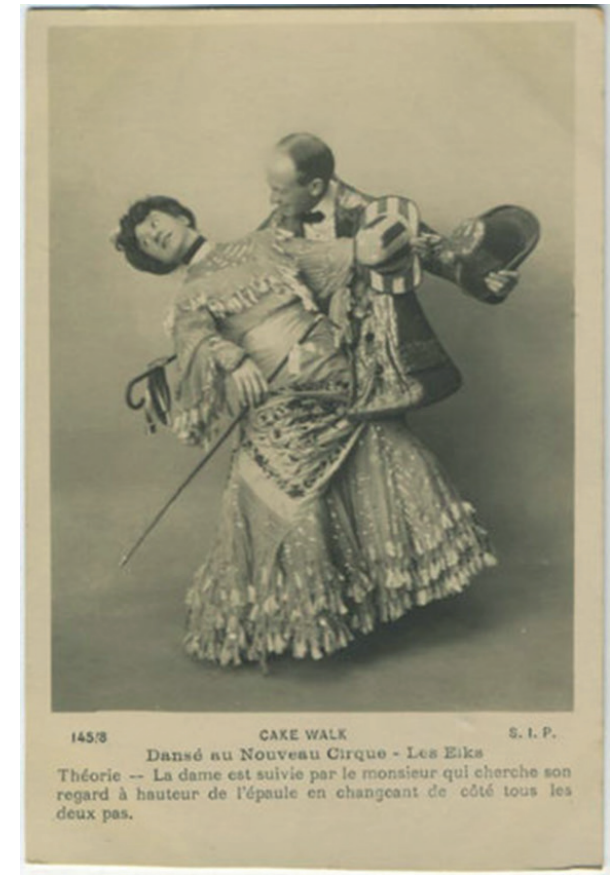

Figure 4: Promotional Card for Les Elks at the Nouveau Cirque, 1902.

19 Their background is unknown, like that for many of the entertainers of the period, but the advertising does refer to "Les Elks" ("Mr. and Mrs.") as notable practitioners from the American circuit. 
Les Elks were accompanied on stage by two "Négrillons," who themselves attracted considerable attention in the press, ${ }^{20}$ and the slapstick comedy of the mixed racial clown pair Foottit and Chocolat. ${ }^{21}$ "Les Joyeux Nègres" at the Nouveau Cirque provided the city's populace with a glimpse of what an anonymous reviewer in Le petit bleu de Paris from December 18, 1902 described as "une danse de sauvages" (Gordon 2010, p. 64) and what Jean Cocteau would recall in 1935 as "crochu" ("bent"), "arrachant" ("wrenching"), and "martelant" ("hammering"), stressing angularity and awkwardness (Cocteau 1935, p. 7). Unfortunately, we do not know which specific music they performed, since variety programs only indicated acts and not their individual numbers.

It is important, however, that the show featured both white minstrels (not in blackface) and African-Americans: the complexity introduced by a mixed racial performance belies any attempt to whiten "Les Joyeux Nègres," or at least to minimize its racialized aspects. The white artists Les Elks certainly dominate the published images from the show, but the scholar could interpret this to imply the dance's appropriation by the dominant culture. In fact, the sheet music for the Cake-walk-polka sur des motifs de Louis Varney implies as much when it asserts about the cake walk that "those stylish New Yorkers knew how to modify the danse de nègres into an original dance for sophisticated tastes, while preserving its individual character." 22 And not unlike the publicity cards for Les Elks, this page of "théorie" made the sheet music indispensable for anyone who wished to learn the dance.

20 Caddy (2007) does not refer to their racial identity.

21 Regarding Foottit and Chocolat, see above all Gordon (2010, p. 160-163).

22 "Les élégants de New-York ont su modifier cette danse de nègres et en faire une danse originale et de bon goût, tout en lui conservant son caractère particulier" (Létorey 1903). 


\section{Le Cake Walk}

ou la "DANSE DU GATEAU"

-梀

Les élégants de New-York ont su modifier cette danse de nègres et en faire une danse originale et de bon goút, tout en lui conservant son caractère particulier.

Théorie de $M^{\text {ne }}$ MARIE HOLTZER

Les danseurs, pendant les quelques mesures dintroduction, vont chercher les dames, les saluent, leur offrent la main droite (la dame y place sa main gauche). et les conduisent pour se placer dans la position du quadrille. Se tenant toujours par la main, ils font un tour sur place en marchant, levant en même temps les bras à demi allongés devant eux, les mains tombantes, les épaules en arrière, se renversant le plus possible, procédant par petits sauts de chaque pied, relevant les genoux a la hauteur de la hanche et battant la mesure avec les mains. Puis ils font un rond en se suivant pour revenir à leur place. - Le premier couple se détache pour se placer au milieu. Le cavalier quitte la main de sa dame et passe derrière elle à droite et à gauche. Ils se regardent gracieusement, continuant le mème pas sur place. Le danseur reprend ensuite la main de sa dame et ils reviennent tous deux à leur place, pour faire un rond avec les autres couples.

Ceux-ci exécutent tour à tour la même figure. Ensuite tous les danseurs tournent autour des dames, marquant tous le même pas sur place.

Pour finir, les danseurs reprennent la main des dames et font le tour du salon en se suivant, toujours marquant le pas sauté, et toujours plus vite jusqu’à la fin de la musique.

Paris, HU MENESTRELr, $2^{\text {bis }}$, rue Vivienne, HEUGEL \& $C^{\text {ie }}$, Éditeurs pour tous pays.

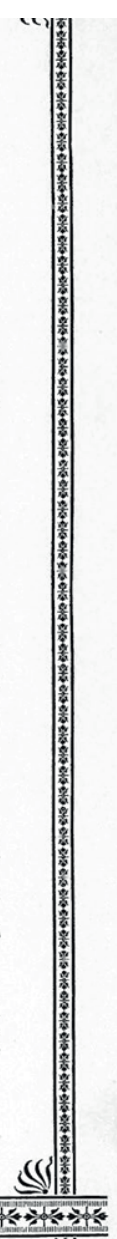

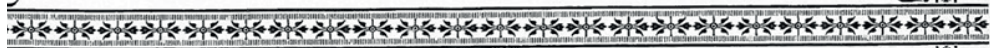

Tous droits ac traduction et de revroduction reserwic.

Figure 5: Marie Holtzer, "Le Cake Walk ou la 'Danse du Gâteau.' Théorie," from Pierre Létory,

Cake-walk-polka sur des motifs de Louis Varney, Paris, Au Ménestrel, 1903.

At the same time, an all-black act performed in the Casino de Paris through at least mid-1903, under the name of the Florida Creole Girls (Smith and Grieg 2003, p. 100). The two sets of publicity photos were taken sometime in 1902 by the Parisian studio of Lucien Walery ${ }^{23}$ - authorized by the dancers themselves, the images reflected two sides of their stage personae: the one set of photographs reveal their playfulness, while the other suggests an exotic eroticism. These performer-generated photographic representations contrast quite vividly from the racially degrading stereotypes that occurred on the covers of cakewalks from the period, and also from the illustrations of Les Elks and their interpretation of the cakewalk. 


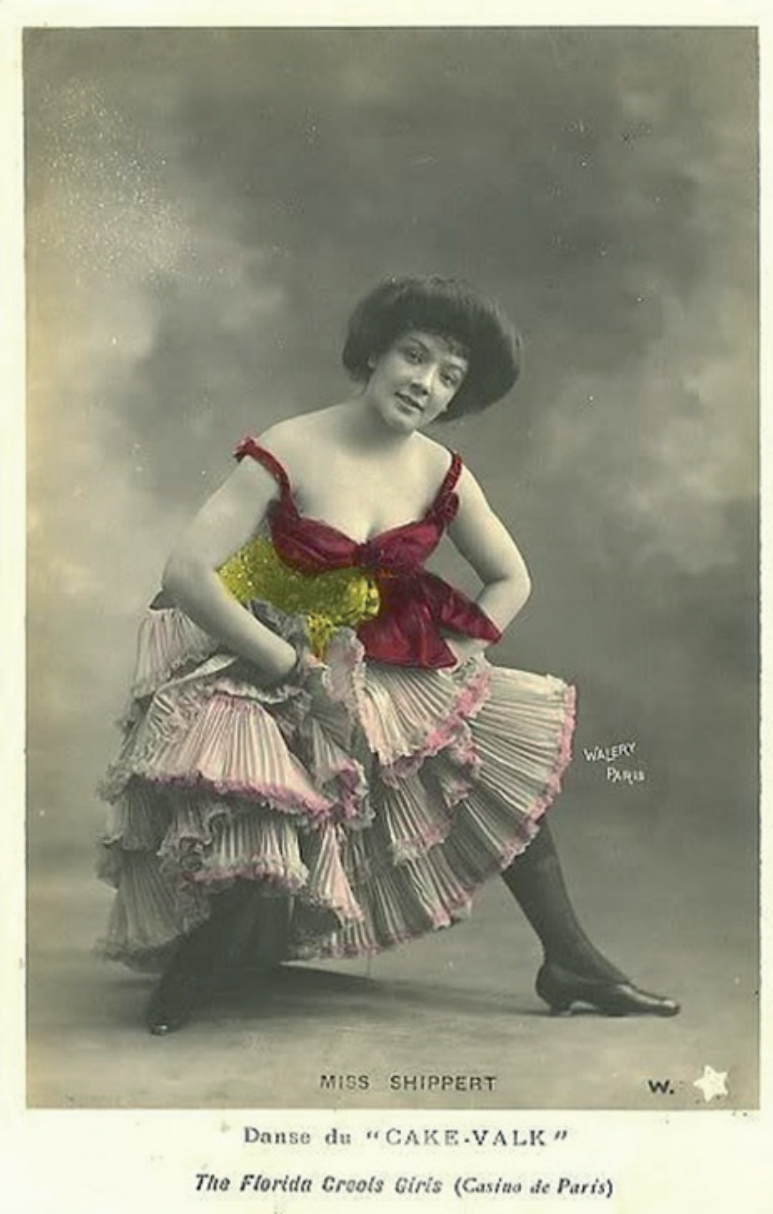

Figure 6: Lucien Walery, "Miss Shippert. Danse du 'cake-valk'. The Florida Creole Girls," 1902.

Other black acts followed in Paris, as early as 1903 according to specialist Rainer Lotz: he proposes that Belle Davis and her Piccaninnies may have also occupied the stage of the Nouveau Cirque in 1903, and definitely played the Alhambra in June of 1905 and October and November of 1906 (Lotz 1994). The photographic record also documents appearances by Les Soeurs Péres at the Nouveau Cirque sometime between 1903 and 1905 and by Les Enfants Nègres at the same venue in 1905, among others. Such appearances were quite popular, drawing upon the incipient modernist negrophilia that found resonance also in literature by, among others, Guillaume Apollinaire and André Salmon and in art by Henri Matisse and Pablo Picasso. ${ }^{24}$ It stands to reason that a backlash to the cakewalk would also occur, as exemplified by the following passage from Le monde illustré of 21 February 1903:

24 Most recent studies focus on the phenomenon of French negrophilia in the 1920s, as manifested in the fetishization of a figure like Josephine Baker. As Andrew Shelton remarks, "it was not until after the First World War that 'negrophilie' really began to engulf Paris” (Shelton 1995, p. 51). 
Is is a dance carried from the Gabon to the Guadeloupe; the negers from the Gabon learned it from the monkeys before they teach it to us. To you, Darwin! [...] Thus, it is the neger art which triumph at this moment. [...] And then we accept the cakewalk as a national dance. Why?" 25

While the Parisian sheet-music industry did publish leading American cakewalks like Kerry Mills' Whistling Rufus and Arthur Pryor's The Coon Band Contest under license (Whiting 2002, p. 300), French composers took up the "danse du gâteau" themselves so that for the first half of 1903, Stephen Whiting indicates over 60 cakewalks appeared in print in Paris. As Whiting remarks, "many have titles and cover illustrations that fully match their American counterparts in casual and (by modern standards) distressing racism" (ibid., p. 300-301). Some of the scores include the "théories" as instructions for the dance, and many illustrate black or white dancers in joyful motion as we saw in Létorey's Cake-walk-polka sur des motifs de Louis Varney. The quantity of scores would abate within the first year as the craze lost its initial novelty, yet the interest in French appropriations of the primitivist dance nevertheless persisted, as illustrated by Hachette's 1907 collection of French cakewalks under the title Cake Walk Album. ${ }^{26}$

As already suggested, pioneering French film-maker Méliès also took an active interest in the danse du gâteau, which led to his creation of the aforementioned Le cake-walk infernal in 1903, the first narrative film using the cakewalk. ${ }^{27}$ Like in his other films, we find here a fantastic and magic-laden scenario, this time in hell, where God, Satan, a few devils, a minstrel couple and back-up dancers perform in what Caddy (2007) aptly designates as "a sort of cakewalk jam session." 28 The action in this film combines and contrasts actual dance steps with displays of athleticism in a display of modern bodies in motion, through the modern medium of cinema.

It stands to reason that at the contemporary screenings, the theatre musician or musicians would have played someone's version of the dance as the women and minstrel couple cakewalked their way through hell. This screen capture portrays the minstrel couple leading the white female cakewalkers in a scene that, "in depicting the black couple as the centrepiece of the number,... [cultivates] the stereotypical

25 "C'est une danse apportée du Gabon à la Guadeloupe; les nègres du Gabon l'auraient apprise des singes avant de nous l'enseigner. À toi, Darwin! [...] C'est donc l'art nègre qui triomphe en ce moment [...] Et voici que nous acceptons le cake-walk comme danse nationale! Pourquoi ?" H.F., writing in Le monde illustré, 21 February 1903, p. 184, as cited in Rae Beth Gordon (2010, p. 77).

26 The volume's contents include "The Elks American Cake Walk," which gives some idea of their continuing popularity after five years.

27 A sizeable bibliography exists for Méliès. Most relevant for the topic of his relationship to dance and the cakewalk is Rae Beth Gordon (2003), "Natural Rhythm. La Parisienne Dances with Darwin: 1875-1910," Modernism/Modernity, vol. 10, no 4, p. 617-656. For the full film without added music, see: http://www.youtube.com/watch?v=IPkxj CLNGU.

28 Caddy and Blake furnish detailed descriptions for the dance, as does Elizabeth Ezra in her study Georges Méliès (Ezra 2000, p. 145-146). Despite an interesting reading of the context for the dance, Caddy problematically designates the film's cake walk as being "made over, dislocated from any of the racial or physical impressions noted earlier." While she does recognize the presence of a "minstrel couple," she fails to interpret the implications of their traditional cakewalk steps in blackface. 
link between Africans and dance, promoting a racial identity subsumed in corporeal agility and rhythm" (Ezra 2000, p. 145). In the same year, Pathé also created a fictional film with the cakewalk as its central theme, Le cake-walk chez les nains, which featured dancers exiting the hat of a magician (Strożek 2013, p. 47).

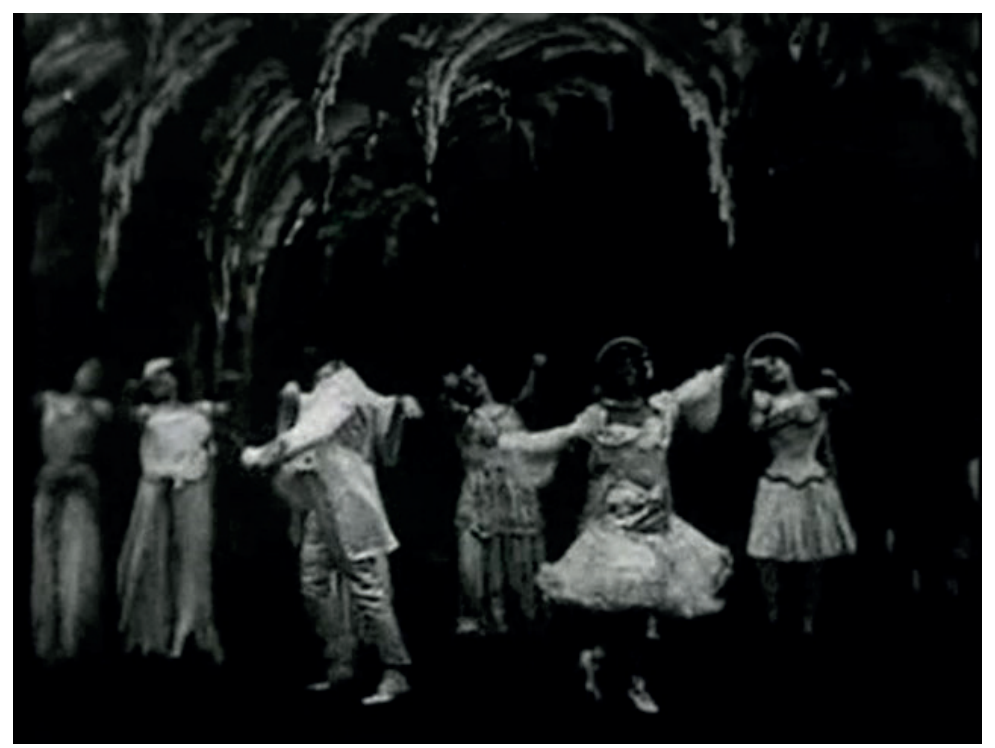

Figure 7: Still from Georges Méliès' film, Le cake-walk infernal, 1903.

\section{CONCLUSION}

This was the Parisian world of the cakewalk in which Debussy lived and worked. Somewhat surprising is how late he came to exploiting the dance for his own purposes, at a time when the early mania had subsided, even though the cakewalk would remain an important feature of the Parisian social scene up to World War I. There is no reason to believe that the composer, as an aficionado of the Nouveau-Cirque, would not have had some contact with the dance in performance in 1903: after all, he did (negatively) review the Sousa band playing this music, ${ }^{29}$ although Sousa used the designation "ragtime" for the cakewalks he conducted.

Debussy had individual reasons for writing the various cakewalk-based pieces, which are partially documented in his correspondence and first-hand biographical accounts and which the secondary literature has already presented and (individually) considered: this evidence includes the general knowledge of his relationship with daughter Claude-Emma ("Chouchou") as a motivating factor behind Golliwogg's Cake-Walk (McKinley 1986, p. 249), the reference to the cakewalk in his August, 1905 letter to Louis Laloy, ${ }^{30}$ and a meeting of Debussy with the racially mixed pair of

29 See for example Bierly (2001, p. 136).

30 "I've just spent several days in London - rather dreary, except for the music of the grenadiers who went past everyday morning with their lively 'bag-pipes' and raucous little fifes. Their marches sound to me like a drunken cross between Scottish popular song, and the Kake-Walch” (Debussy 1987, p. 160). 
dancing clowns Foottit and Chocolat. ${ }^{31}$ We are also aware of his infamous letters to Durand about exotic dancer Maud Allan, in which Debussy records remarks that we find today racially offensive. ${ }^{32}$

There can be no doubt that his cakewalk-based works originated as a result of Debussy's relationship with the culture of his times, with the modernist negrophilia, as embodied in the cakewalk. The point may be obvious, but it is worth stating: Debussy never composed a real cakewalk, but rather seems to have exploited the dance with its characteristic syncopations for its rhythmic interest, "couleur" and novelty. ${ }^{33}$ That they all display tongue-in-cheek, playful elements, if not outright satire, suggests a certain distancing from the practices behind the performances. Nevertheless, we probably will never know what motivated Debussy to compose this music, but we can say that his cakewalk-based compositions arose in a world where the performance of race accomplished important cultural and social work, above all for individual and corporate identity in the age of modernism.

\section{BIBLIOGRAPHY}

Akinwande, Pierre (2011), Négritude et francophonie. Paradoxes culturels et politiques, Paris, L'Harmattan.

Albright, Daniel (2000), Untwisting the Serpent. Modernism in Music, Literature, and Other Arts, Chicago, University of Chicago Press.

Bierly, Paul E. (2001), John Philip Sousa. American Phenomenon, Miami, Warner Bros. Publications.

Bierly, Paul E. (2006), The Incredible Band of John Philip Sousa, Urbana, IL, University of Illinois Press.

Blake, Jody (1999), Le Tumulte Noir. Modernist Art and Popular Entertainment in Jazz-Age Paris, 1900-1930, University Park, PA, Pennsylvania State University Press.

Brown, Matthew (2012), Debussy Redux. The Impact of His Music on Popular Culture, Bloomington, IN, Indiana University Press.

Bruhn, Siglind (1997), Images and Ideas in Modern French Piano Music. The Extra-Musical Subtext in Piano Works by Ravel, Debussy, and Messiaen, Stuyvesant, NY, Pendragon Press.

Burt, Ramsay (1998), Alien Bodies. Representations of Modernity, "Race" and Nation in Early Modern Dance, London, Routledge.

Caddy, Davinia (2007), "Parisian Cake Walks," 19th-Century Music, vol. 30, nº 3, p. 288-317.

Cocteau, Jean (1935), Portraits-souvenir. 1900-1914, Paris, Grasset.

Cummins, Linda (2006), Debussy and the Fragment, Amsterdam, Rodopi.

31 Debussy talked with the two at the popular Bar Reynolds (Lockspeiser 1978, p. 136-137).

32 Orledge recounts the relationship this way: "He complained to Durand that she had supplied him with 'a scenario so boring that a Negro could have done better.' And when he had not heard from her for a while in 1913, he imagined that 'the undulating Miss Allan was dancing for some Negro race in darkest West Africa"' (Orledge 2003, p. 13).

33 Kramer puts it this way: "Debussy does not so much write a cakewalk as portray one" (Kramer 2004, p. 113). 
Deaville, James (2002), "Cakewalk in Waltz Time? African-American Music in Jahrhundertwende Vienna," in Susan Ingram, Markus Reisenleitner and Cornelia Szabó-Knotik (ed.), Reverberations. Representations of Modernity, Tradition and Cultural Value in/between Central Europe and North America, Frankfurt am Main, Peter Lang, p. 17-39.

Debussy, Claude (1987), Debussy Letters, translated by Roger Nichols, Cambridge, MA, Harvard University Press.

Ezra, Elizabeth (2000), Georges Méliès, Manchester, UK, Manchester University Press.

Fletcher, Tom (1984), 100 Years of the Negro in Show Business, New York, Da Capo.

Gendron, Bernard (1990), "Fetishes and Motorcars. Negrophilia in French Modernism," Cultural Studies, ${ }^{\circ}$ 4, p. 141-155.

Gordon, Rae Beth (2003), "Natural Rhythm. La Parisienne Dances with Darwin: 1875-1910," Modernism/modernity, vol. 10, n 4, p. 617-656.

Gordon, Rae Beth (2009), Dances with Darwin, 1875-1910. Vernacular Modernity in France, Farnham, UK, Ashgate.

Gordon, Rae Beth (2010), "Les rythmes contagieux d'une danse noire. Le cake-walk," Intermédialités. Histoire et théorie des arts, des lettres et des techniques, $\mathrm{n}^{\circ} 16, \mathrm{p}$. 57-81.

Huebner, Steven (1999), French Opera at the Fin-de-Siècle. Wagnerism, Nationalism, and Style, Oxford, Oxford University Press.

Jakobson, Roman ([1979]1985), "Roman Jakobson Interviewed by David Shapiro," Sulfur, no 12.

Jordan, Matthew F. (2010), Le Jazz. Jazz and French Cultural Identity, Urbana, IL, University of Illinois Press.

Kramer, Lawrence (2004), Opera and Modern Culture. Wagner and Strauss, Berkeley, University of California Press.

Kramer, Lawrence (1996), "Powers of Blackness. Africanist Discourse in Modern Concert Music," Black Music Research Journal, n 16, p. 53-70.

Krasner, David (2011), "The Real Thing," in W. Fitzhugh Brundage (ed.), Beyond Blackface. African Americans and the Creation of American Popular Culture, Chapel Hill, NC, University of North Carolina Press, p. 99-123.

Krüger, Klaus, Crasemann, Leena, and Matthias Weiß (2010), Um/Ordnungen. Fotografische Menschenbilder zwischen Konstruktion und Destruktion, Munich, Wilhelm Fink.

Létorey, Pierre (1903), Cake-walk-polka sur des motifs de Louis Varney, Paris, Au Ménestrel.

Lockspeiser, Edward (1978), Debussy. His Life and Mind, "Vol. 1. 1862-1902," Cambridge, Cambridge University Press.

Lotz, Rainer E. (1994), "Belle Davis and Her Piccaninnies. A Preliminary Bio-, Disco-, and Filmography," Association for Recorded Sound Journal, n 25, p. 178-191.

Lussan-Borel (1899), Traité de danse, avec musique, contenant toutes les danses de salon avec une théorie nouvelle de valse et boston, du cotillon et du cake-walk, Paris, Flammarion.

McKinley, Ann (1986), "Debussy and American Minstrelsy," The Black Perspective in Music, $\mathrm{n}^{\circ} 14$, p. 249-258.

Marion, Gregory (2007), "Debussy and Recollection. Trois apercu [sic]," Music Theory Online, vol. 13, $\mathrm{n}^{\circ}$ 1, http://www.mtosmt.org/issues/mto.07.13.1/mto.07.13.1.marion.html\#FN44, accessed 1st June, 2013.

Martelly, Elizabeth de (2010), "Signification, Objectification, and the Mimetic Uncanny in Claude Debussy's Golliwogg's Cake-Walk," Current Musicology, nº 90, p. 7-34.

Frauser, Annegret, and Mark Everist (ed.) (2009), Music, Theater, and Cultural Transfer: Paris, 1830-1914, Chicago, University of Chicago Press.

Orillo Verzosa, Noel (2009), "The Absolute Limits. Debussy, Satie, and the Culture of French Modernism, ca. 1860-1920," PhD dissertation, University of California, Berkeley. 
Orledge, Robert (2003), "Debussy the Man," in Simon Tresize (ed.), The Cambridge Companion to Debussy, Cambridge, Cambridge University Press, p. 9-24.

Schwartz, Vanessa R. (1998), Spectacular Realities. Early Mass Culture in Fin-de-Siècle Paris, Berkeley, University of California Press.

Schultz, Joachim (1990), "Ulysse, Cafre, ou l'histoire dorée d'un noir. Le roman de Marius et Ary Leblond dans le contexte de la littérature française des années vingt," Itinéraires et contacts de cultures, vol. 12, p. 115-123.

Shelton, Andrew (1995), Fetishism. Visualising Power and Desire, London, South Bank Centre.

Smethurst, James Edward (2011), The African American Roots of Modernism. From Reconstruction to the Harlem Renaissance, Chapel Hill, NC, University of North Carolina Press.

Smith, Catherine, and Cynthia Grieg (2003), Women in Pants. Manly Maidens, Cowgirls, and Other Renegades, New York, Harry N. Abrams.

Strożek, Przemysław (2013), "Futurist Responses to African American Culture," in Fionnghuala Sweeney et Kate Marsh (ed.), Afromodernisms. Paris, Harlem, Haiti and the Avant-Garde, Edinburgh, Edinburgh University Press, p. 43-61.

Taruskin, Richard (2008), The Danger of Music and Other Anti-Utopian Essays, Berkeley, CA, University of California Press.

Waldo, Terry (1991), This is Ragtime, New York, Da Capo Press.

Whiting, Steven (2002), Satie the Bohemian. From Cabaret to Concert Hall, Oxford, Oxford University Press. 